\title{
Pancreatic Insulinoma
}

National Cancer Institute

\section{Source}

National Cancer Institute. Pancreatic Insulinoma. NCI Thesaurus. Code C95598.

An insulin-producing neuroendocrine tumor arising from the beta cells of the pancreas.

Patients exhibit symptoms related to hypoglycemia due to inappropriate secretion of insulin. 